\title{
Aktivitas Gastroprotektif Ekstrak Etanol Daun Gedi Hijau (Abelmoschus manihot (L.) Medik) Terhadap Tikus Putih Jantan (Rattus norvegicus L.) Yang Diinduksi Dengan Aspirin
}

\author{
Gastroprotective Activity Of Ethanolicextract Of The Leaves Of \\ Abelmoschus manihot (L.) Medik Against Aspirin Induced White Rats \\ (Rattus norvegicus L.) \\ Ni Made Susilawati ${ }^{1}$, Yuliet $^{2}$, Khildah Khaerati ${ }^{2)}$ \\ ${ }^{1)}$ Jurusan Farmasi, Fakultas MIPA, Universitas Tadulako, Palu. \\ ${ }^{2}$ Laboratorium Farmakologi-Biofarmasi Jurusan Farmasi, Fakultas MIPA, Universitas Tadulako, Palu.
}

\begin{abstract}
Abelmoschus manihot (L.) Medik contains flavonoid, alkaloid, tannin and saponinthat prevent peptic ulcer disease. This study aimed to examine the gastroprotective activity and the effective dose of A. manihot (L.) Medikleaves extract as gastroprotector to aspirin induced white rats. Extract was found by using ethanol $96 \%$ in maseration method. The sample was twenty four rats divided into 6 groups. All rats were given oral treatment for 3 days: normal control group was given $0,5 \% \mathrm{Na}-\mathrm{CMC}$; negative control group was given $0,5 \% \mathrm{Na}-\mathrm{CMC}+$ Aspirin $600 \mathrm{mg} / \mathrm{kg} \mathrm{BW}$; positive control group was given Sucralfate suspension $360 \mathrm{mg} / \mathrm{kg} \mathrm{BW}+$ Aspirin $600 \mathrm{mg} / \mathrm{kg} \mathrm{BW}$; the dose test group 1was given ethanol extract of A. manihot (L.) Medikleaves $100 \mathrm{mg} / \mathrm{kg} \mathrm{BW}+$ Aspirin $600 \mathrm{mg} / \mathrm{kg} \mathrm{BW}$; the dose test group 2 was given ethanol extract of A. manihot (L.) Medikleaves $200 \mathrm{mg} / \mathrm{kg} \mathrm{BW}+$ Aspirin $600 \mathrm{mg} / \mathrm{kg} \mathrm{BW}$; the dose test group 3 was given ethanol extract of A. manihot (L.) Medikleaves $300 \mathrm{mg} / \mathrm{kg} \mathrm{BW}+$ Aspirin $600 \mathrm{mg} / \mathrm{kg} \mathrm{BW}$. On third day, rats were sacrificed 4 hours latter after aspirin treatment. Stomachs were taken for determining index ulcer and percentage of ulcer inhibition. The data were analyzed absed onKruskal Wallis and Mann Whitney statistical test at $\alpha=0,05$. The result showed that $A$. manihot (L.) Medikleaves extract can prevent mucosal damage on rats. Effective gastroprotective dose of extract of A. manihot (L.)Medik leaves was $300 \mathrm{mg} / \mathrm{kg}$ BW which equal to Sucralfate.
\end{abstract}

Keywords: Abelmoschus manihot (L.) Medik, gastroprotective, aspirin.

\begin{abstract}
ABSTRAK
Gedi hijau (Abelmoschus manihot (L.)Medik ) mengandung flavonoid, alkaloid, tannin, dan saponin yang mampu melindungi mukosa lambung. Penelitian ini bertujuan untuk mengetahui aktivitas gastroprotektif serta untuk mengetahui dosis efektif ekstrak etanol daun gedi hijau dalam pemberian efek gastroprotektif terhadap tikus putih jantan yang diinduksi dengan aspirin. Ekstrak diperoleh dengan cara maserasi menggunakan pelarut etanol $96 \%$. Sampel terdiri dari 24 ekor tikus putih jantan (Rattus norvegicus L.) dibagi dalam 6 kelompok. Perlakuan diberi per oral selama 3 hari meliputi: Kelompok kontrol normal diberi
\end{abstract}


0,5\% Na-CMC; kelompok kontrol negatif diberi 0,5\% Na-CMC + Aspirin $600 \mathrm{mg} / \mathrm{kg} \mathrm{BB}$; kelompok kontrol positif diberi suspensi Sukralfat $360 \mathrm{mg} / \mathrm{kg} \mathrm{BB}+$ Aspirin $600 \mathrm{mg} / \mathrm{kg} \mathrm{BB}$; kelompok dosis uji 1 diberi ekstrak etanol daun gedi hijau $100 \mathrm{mg} / \mathrm{kg}$ BB + Aspirin 600 $\mathrm{mg} / \mathrm{kg} \mathrm{BB}$; kelompok dosis uji 2 diberi ekstrak etanol daun gedi hijau $200 \mathrm{mg} / \mathrm{kg} \mathrm{BB}+$ Aspirin $600 \mathrm{mg} / \mathrm{kg} \mathrm{BB}$; kelompok dosis uji 3 diberi ekstrak etanol daun gedi hijau $300 \mathrm{mg} / \mathrm{kg}$ $\mathrm{BB}+$ Aspirin $600 \mathrm{mg} / \mathrm{kg} \mathrm{BB}$. Pada hari ke 3, tikus dibedah 4 jam setelah pemberian aspirin, diambil organ lambung untuk dilakukan perhitungan indeks ulser dan persen inhibisi. Data dianalisis menggunakan uji statistik Kruskal Wallis dan uji statistik Mann Whitney dengan $\alpha$ $=0,05$. Hasil penelitian menunjukkan bahwa ekstrak daun gedi hijaudapat mencegah kerusakan mukosa lambung tikus yang dipapar aspirin dengan dosis efektif adalah $300 \mathrm{mg} / \mathrm{kg}$ BB yang sebanding dengan sukralfat.

\section{aspirin.}

Kata kunci: Gedi hijau(Abelmoschus manihot (L.) Medik ), gastroprotektif,

\section{LATAR BELAKANG}

Ulkus peptikum terjadi karena adanya ketidakseimbangan antara faktor pertahanan mukosa (bikarbonat, musin, prostaglandin, nitrogen monoksida (NO) serta faktor pertumbuhan) dan faktor agresif (asam dan pepsin). Hal ini dapat disebabkan oleh beberapa hal diantaranya yaitu infeksi Helicobacter pylori, penggunaan obat antiinflamasi nonsteroid (OAINS) jangka panjang ataupun disebabkan akibat stres (Gilman, 2012).

Pendekatan pengobatan yang telah dilakukan untuk mengatasi penyakit ini yaitu dengan menghilangkan infeksi H.pylori, mengurangi sekresi asam lambung atau menetralkan asam setelah disekresikan, serta menyediakan obat-obat yang melindungi mukosa lambung dari kerusakan (Mycek, 2001). Namun perlu diketahui bahwa penggunaan obat-obat sintetik memiliki beberapa efek samping yang dapat ditimbulkan.
Saat ini minat masyarakat terhadap obat tradisional sebagai salah satu bentuk jenis pengobatan semakin meningkat dikarenakan penggunaan tanaman berkhasiat obat memiliki beberapa keuntungan yang menarik minat masyarakat untuk menggunakannya. Secara global, diprediksikan bahwa $80 \%$ dari populasi penduduk dunia menggunakan obat tradisional dalam pengobatannya (Rivera et al., 2013).

Salah satu tanaman obat yang dapat digunakan dalam penanganan ulkus peptikum adalah daun gedi hijau (Abelmoschus manihot (L.)Medik). Berdasarkan informasi yang digali oleh peneliti terhadap key informan yang berasal dari desa Tinggede, kecamatan Marawola, kabupaten Sigi, Sulawesi Tengah diketahui bahwa sebagai pencegahan penyakit ini, 15 helai daun gedi hijau direbus dengan menggunakan air hingga air rebusan menjadi hijau 
bening dan menjadi kental lalu air rebusan diminum dalam keadaan hangat.

Berdasarkan penelitian terkait, yaitu pemberian musilago biji gedi (Abelmoschus esculentus) secara oral pada tikus yang diinduksi dengan etanol, indometasin dan stres yang diakibatkan dari pencelupan di air, secara signifikan dapat menghambat ulser dengan pemberian musilago dari biji gedi pada dosis $1 \mathrm{~g} / \mathrm{kg}$ BB. Kandungan polisakarida musilago ekstrak biji gedi diduga memberikan efek sitoprotektif terhadap lambung tikus yang diinduksi dengan agen pencetus ulkus peptikum (Joshi et al., 2011). Selain itu juga, efek yang sama didapatkan karena adanya zat-zat lain seperti flavonoid (Kumar et al., 2013), saponin, alkaloid serta tanin (Mbagwu et al., 2011).

Oleh karena itu, berdasarkan uraian di atas, peneliti tertarik untuk meneliti aktivitas gastroprotektif ekstrak etanol daun gedi hijau (Abelmoschus manihot (L.)Medik) terhadap tikus putih jantan (Rattus norvegicus L.) yang diinduksi dengan aspirin.

\section{BAHAN DAN METODE Bahan}

Bahan uji yang digunakan dalam penelitian ini yaitu ekstrak etanol daun gedi hijau. Bahan-bahan kimia yang digunakan dalam penelitian ini yaitu akuades, etanol, aspirin (FARMA GRADE $^{\circledR}$ ), suspensi sukralfat (EPISAN ${ }^{\circledR}$ ), natrium karboksi metil selulosa, natrium klorida fisiologis $\left(\right.$ OTSUKA $\left.^{\circledR}\right)$, pereaksi Dragendorff, pereaksi Mayer, pereaksi Wagner, pereaksi Liebermann Burchard, asam klorida, eter, asam sulfat, amonia, besi (III) klorida.

\section{Hewan Uji}

Hewan uji yang digunakan yaitu tikus putih jantan (Rattus norvegicus L.), berumur 3-4 bulan dengan berat badan 150-300 g. Tikus diadaptasikan selama 1 minggu dalam kandang dan dipuasakan namun tetap diberi air (ad libitum) selama 12 jam sebelum diberi perlakuan.

\section{Metode Penelitian}

Jenis penelitian ini ialah jenis penelitian eksperimental menggunakan metode rancangan acak lengkap (RAL) dengan menggunakan 6 kelompok perlakuan yaitu kontrol normal, kontrol negatif, kontrol positif, dan kelompok perlakuan dengan variasi tiga dosis yang selanjutnya data yang diperoleh diuji dengan uji statistik Kruskal-Wallis ( $\alpha=$ 0,05) yang dilanjutakan dengan uji MannWhitney dengan nilai $\alpha=0,05$.

\section{Waktu dan Tempat Penelitian}

Penelitian ini dilaksanakan pada bulan November 2015 hingga Februari 2016. Penelitian ini dilaksanakan di Laboratorium Farmakognosi-Fitokimia 
dan di Laboratotium Farmakologi-

Biofarmasi Jurusan Farmasi, Fakultas

Matematika dan Ilmu Pengetahuan Alam,

Universitas Tadulako, Palu, Sulawesi

Tengah.

\section{Tahap Persiapan Bahan Uji}

Bahan uji yang digunakan dalam penelitian ini merupakan daun dari tumbuhan gedi hijau yang didapatkan di Desa Lolu, Kecamatan Sigi Biromaru, Kabupaten Sigi, Sulawesi Tengah.Identifikasi tanaman gedi hijau dilakukan di Pusat Konservasi Tumbuhan Kebun Raya - LIPI Bogor, kabupaten Bogor, Jawa Barat.

Waktu pengambilan daun gedi hijau dilakukan pada pagi hari.Bagian yang diambil merupakan bagian daun kelima dari pucuk hingga ke bawah yang masih berwarna hijau.Adapun teknik pengambilan sampel dilakukan dengan pemetikan daun secara langsung dengan menggunakan tangan.Selanjutnya, dilakukan sortasi basah.Kemudian dicuci dengan air yang mengalir.Berikutnya dilakukan perajangan dan dikeringkan tanpa terpapar langsung oleh cahaya matahari hingga hasil rajangan daun gedi hijau menjadi kering.Setelah daun gedi hijau menjadi kering kemudian dilakukan sortasi kering sehingga didapatkan simplisia daun gedi. Selanjutnya simplisia diserbukkan dengan menggunakan blender dan diayak dengan ayakan mesh 40 .

\section{Tahap Ekstraksi}

Serbuk simplisia daun gedi hijau diekstraksi dengan menggunakan metode maserasi menggunakan pelarut etanol $96 \%$ selama 3x24 jam dalam bejana maserasi wadah kaca dengan pengadukkan setiap 1x24 jam. Hasil dari proses maserasi disaring dengan kertas saring, dan filtrat diuapkan dengan menggunakan alat Vaccum Rotary Evaporator hingga didapatkan hasil berupa ekstrak kental. Setelah itu, pH ekstrak kental diukur dengan menggunakan $\mathrm{pH}$ meter.

\section{Tahap Uji Penapisan Fitokimia}

Ekstrak daun gedi hijau yang didapatkan kemudian diuji kualitatif terhadap adanya senyawa flavonoid, fenolik, saponin, steroid, triterpenoid, alkaloid dan tannin.

\section{Tahap Pengujian Gastroprotektif}

Tikus sebanyak 24 ekor dikelompokkan ke dalam 6 kelompok secara acak sehingga tiap kelompok percobaan terdiri atas 4 tikus.Perlakuan dilakukan secara per oral sekali sehari selama 3 hari pada setiap kelompok.

Kelompok kontrol normal diberi 0,5\% Na-CMC; kelompok kontrol negatif diberi 0,5\% Na-CMC + Aspirin $600 \mathrm{mg} / \mathrm{kg}$ $\mathrm{BB}$; kelompok kontrol positif diberi suspensi sukralfat $360 \mathrm{mg} / \mathrm{kg} \quad \mathrm{BB} \quad+$ 
Aspirin 600 mg/kg BB; kelompok dosis uji 1 diberi ekstrak etanol daun gedi hijau 100 $\mathrm{mg} / \mathrm{kg} \mathrm{BB}+$ Aspirin $600 \mathrm{mg} / \mathrm{kg} \mathrm{BB}$; kelompok dosis uji 2 diberi ekstrak etanol daun gedi hijau $200 \mathrm{mg} / \mathrm{kg}$ BB + Aspirin $600 \mathrm{mg} / \mathrm{kg} \mathrm{BB}$; kelompok dosis uji 3 diberi ekstrak etanol daun gedi hijau 300 $\mathrm{mg} / \mathrm{kg} \mathrm{BB}+$ Aspirin $600 \mathrm{mg} / \mathrm{kg}$ BB. Aspirin diberikan setelah 1 jam pemberian $0,5 \% \mathrm{Na}-\mathrm{CMC}$, sukralfat dan ekstrak daun gedi hijau. Pada hari ketiga, 4 jam setelah pemberian aspirin semua hewan coba dikorbankan untuk diambil lambungnya dan diberi skor. Adapun skor yang diberikan sebagai berikut: $1=$ bila lesi < $1,00 \mathrm{~mm} ; 2=$ bila lesi $1,00-2,00 \mathrm{~mm} ; 3=$ bila lesi 2,01-3,00 mm; 4 = bila lesi 3,01$4,00 \mathrm{~mm} ; 5=$ bila lesi 4,01-5,00 $\mathrm{mm} ; 10=$ bila lesi $>5,00 \mathrm{~mm} ; 25=$ bila terjadi perforasi (Sari dkk, 2011).

Untuk indeks ulser dan persen hambatan (Oloyede et al, 2015) dihitung dengan menggunakan rumus:

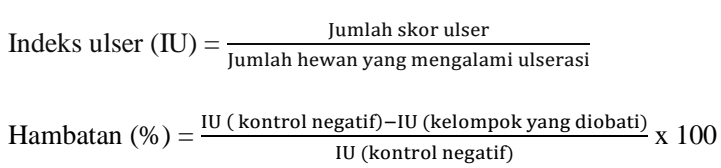

\section{Analisis Data}

Selanjutnya data yang didapatkan dari perlakuan dianalisis secara statistik dengan menggunakan uji statistik KruskalWallis $(\alpha=0,05)$ untuk mengetahui adanya perbedaan seluruh kelompok populasi yang dilanjutkan dengan uji
Mann-Whitney dengan nilai $\alpha=0,05$ untuk mengetahui letak adanya perbedaan dalam populasi.

\section{HASIL DAN PEMBAHASAN}

\section{Hasil Ekstraksi}

Hasil ekstraksi daun gedi hijau menggunakan metode maserasi dengan pelarut etanol $96 \%$ didapatkan bobot ekstrak kental sebanyak 23,81 g dengan hasil rendemen sebesar 1,87 persen (\%) dengan $\mathrm{pH}$ ekstrak 5,26.

\section{Hasil Penapisan Fitokimia}

Hasil penapisan fitokimia ekstrak daun gedi hijau dapat dilihat pada Tabel 1 di bawah ini.

Tabel 1. Hasil penapisan fitokimia ekstrak daun gedi hijau

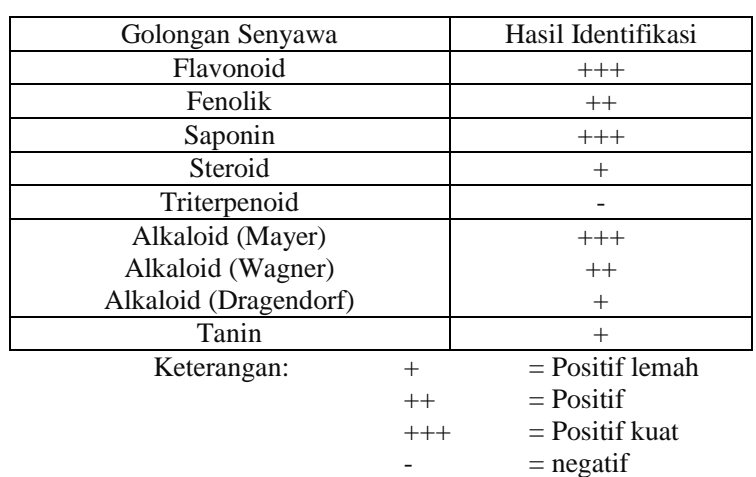

\section{Hasil Skor Lambung}

Berdasarkan hasil uji statistik dengan menggunakan uji statistik KruskalWallis $(\alpha=0,05)$ dan uji Mann-Whitney dengan nilai $\alpha=0,05$, didapatkan hasil yang dapat dilihat pada Tabel 2 di bawah ini.

Tabel 2.Hasil uji statistik skor lambung 


\begin{tabular}{|c|c|c|}
\hline $\begin{array}{c}\text { Kelompok } \\
\text { Perlakuan }\end{array}$ & Nilai P & Keterangan \\
\hline $\mathrm{K}(\mathrm{N})-\mathrm{K}(-)$ & 0,013 & ada perbedaan signifikan \\
\hline $\mathrm{K}(\mathrm{N})-\mathrm{K}(+)$ & 1,000 & tidak ada perbedaan signifikan \\
\hline $\mathrm{K}(\mathrm{N})$ - D3 & 1,000 & tidak ada perbedaan signifikan \\
\hline $\mathrm{K}(\mathrm{N})$ - D2 & 0,040 & ada perbedaan signifikan \\
\hline $\mathrm{K}(\mathrm{N})$ - D1 & 0,008 & ada perbedaan signifikan \\
\hline $\mathrm{K}(+)-\mathrm{D} 3$ & 1,000 & tidak ada perbedaan signifikan \\
\hline $\mathrm{K}(+)-\mathrm{D} 2$ & 0,040 & ada perbedaan signifikan \\
\hline $\mathrm{K}(+)-\mathrm{D} 1$ & 0,008 & ada perbedaan signifikan \\
\hline $\mathrm{K}(-)-\mathrm{K}(+)$ & 0,013 & ada perbedaan signifikan \\
\hline $\mathrm{K}(-)-\mathrm{D} 3$ & 0,013 & ada perbedaan signifikan \\
\hline $\mathrm{K}(-)-\mathrm{D} 2$ & 0,098 & tidak ada perbedaan signifikan \\
\hline $\mathrm{K}(-)$ - D1 & 0,131 & tidak ada perbedaan signifikan \\
\hline $\mathrm{D} 2-\mathrm{D} 3$ & 0,040 & ada perbedaan signifikan \\
\hline $\mathrm{D} 1-\mathrm{D} 3$ & 0,008 & ada perbedaan signifikan \\
\hline $\mathrm{D} 1-\mathrm{D} 2$ & 0,317 & tidak ada perbedaan signifikan \\
\hline
\end{tabular}
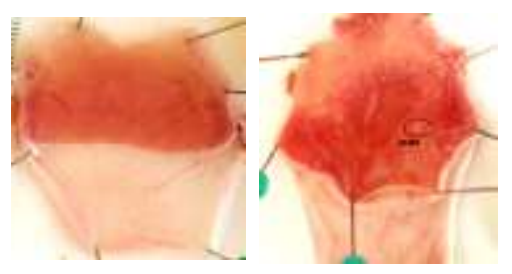

(a)

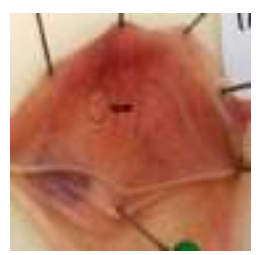

(d)

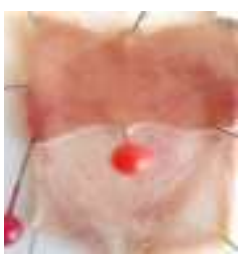

(b)

(c)

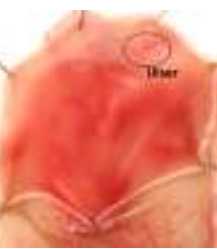

(e)

(f)

$\mathrm{K}(-)$ = Kontrol Negatif

D1 $=$ Dosis $1(100 \mathrm{mg} / \mathrm{kg} \mathrm{BB})$

D2 $=$ Dosis $2(200 \mathrm{mg} / \mathrm{kg} \mathrm{BB})$

D3 $=$ Dosis $3(300 \mathrm{mg} / \mathrm{kg} \mathrm{BB})$

\section{Hasil Indeks Ulser dan Persen Inhibisi}

Data skor lambung yang didapatkan, selanjutnya digunakan untuk menghitung indeks ulser dan persen inhibisi. Indeks ulser dihitung berdasarkan perbandingan antara jumlah total skor ulser dengan jumlah tikus yang mengalami ulserasi. Tingkat penyembuhan dinilai berdasarkan nilai persen inhibisi.Nilai indeks ulser dan persen inhibisi dapat dilihat pada Tabel 3 di bawah ini.

Tabel 3. Nilai indeks ulser dan persen inhibisi

\begin{tabular}{|c|c|c|}
\hline Kelompok Perlakuan & $\begin{array}{c}\text { Indeks } \\
\text { Ulser }\end{array}$ & $\begin{array}{c}\text { Persen } \\
\text { Inhibisi } \\
(\%)\end{array}$ \\
\hline Kontrol Normal & 0 & - \\
\hline Kontrol Negatif & 2,75 & 0 \\
\hline Kontrol Positif & 0 & 100 \\
\hline Dosis 1 (100 mg/kg BB) & 1 & 63,63 \\
\hline Dosis 2 $(200 \mathrm{mg} / \mathrm{kg} \mathrm{BB})$ & 0,75 & 72,73 \\
\hline Dosis 3 $(300 \mathrm{mg} / \mathrm{kg} \mathrm{BB})$ & 0 & 100 \\
\hline
\end{tabular}

\section{Gambar Makroskopik Lambung Tikus}

Berikut gambar penampakan makroskopik lambung tikus dari 6 kelompok perlakuan.

$$
\begin{aligned}
& \text { Keterangan: } \\
& \begin{array}{ll}
\text { (a } & =\text { Kontrol Normal } \\
\text { (b) } & =\text { Kontrol Positif } \\
\text { (c) } & =\text { Kontrol Negatif } \\
\text { (d) } & =\text { Dosis } 1(100 \mathrm{mg} / \mathrm{kg} \mathrm{BB}) \\
\text { (e) } & =\text { Dosis } 2(200 \mathrm{mg} / \mathrm{kg} \mathrm{BB}) \\
\text { (f) } & =\text { Dosis } 3(300 \mathrm{mg} / \mathrm{kg} \mathrm{BB})
\end{array}
\end{aligned}
$$

\section{Pembahasan}

Ulkus peptikum merupakan salah satu jenis penyakit gastrointestinal yang terjadi disebabkan adanya suatu ketidakseimbangan antara faktor pertahanan mukosa (bikarbonat, musin, prostaglandin, nitrogen monoksida (NO) serta faktor pertumbuhan) dan faktor agresif (asam dan pepsin) (Gilman, 2012).

Penelitian ini bertujuan untuk mengetahui aktivitas gastroprotektif ekstrak etanol daun gedi hijau terhadap tikus putih jantan yang diinduksi dengan aspirin.

Proses ekstraksi yang dilakukan menggunakan metode maserasi dengan menggunakan etanol $96 \%$ sebagai cairan penyari. Rendemen ekstrak daun gedi hijau yang diperolehsebesar 1,87\%. pH ekstrak yang diperoleh sebesar 5,26. 
Pengukuran $\mathrm{pH}$ ekstrak daun gedi hijau bertujuan untuk memastikan pemberian ekstrak daun gedi hijau tidak mempengaruhi keasaman lambung sehingga tidak berpengaruh pada aktivitas gastroprotektif ekstrak daun gedi hijau.

Penapisan fitokimia dilakukan untuk mengetahui golongan senyawa yang terkandung pada ekstrak yang digunakan.Penapisan fitokimia yang dilakukan pada ekstrak daun gedi hijau menunjukkan hasil positif terhadap golongan fenolik, flavonoid, alkaloid, saponin, steroid dan tannin.

Penelitian ini menggunakan hewan uji sebanyak 24 yang dibagi ke dalam 6 kelompok secara acak agar setiap kelompok dapat mewakili polulasi tikus sehingga dalam 1 kandang terdiri dari 4 tikus. Pada hari pertama hingga hari ke tiga perlakuan semua hewan uji diberi perlakuan sesuai pembagian kelompok masing-masing.Perlakuan selama 3 hari dilakukan karena diharapkan sediaan/bahan uji telah memberikan efek akumulasi yang optimal untuk memberikan efek gastroprotektif. Pada penelitian ini kontrol normal dan negatif diberikan $\mathrm{Na} \mathrm{CMC}$ 0,5\%, kelompok kontrol positif diberikan suspensi sukralfat $360 \mathrm{mg} / \mathrm{kg}$ BB, sedangkan kelompok uji dosis 1, 2 dan 3 masing-masing diberikan ekstrak daun gedi hijau dengan dosis 100 $\mathrm{mg} / \mathrm{kg} \mathrm{BB}, 200$ mg/kg BB dan 300 mg/kg BB selain itu setelah 1 jam pemberian perlakuan tersebut maka kelompok kontrol negatif, kontrol positif, kelompok uji dosis 1, 2 dan 3 diberikan aspirin dengan dosis 600 mg/kg BB secara oral. Pemberian dilakukan peroral (sonde) karena untuk mendapatkan efek pada saluran cerna maka cara pemberian yang paling tepat untuk dipilih adalah secara oral. Kemudian pada hari ketiga perlakuan setelah 4 jam pemberian aspirin kemudian tikus dikorbankan kemudian dibedah untuk diambil lambungnya lalu lambung tikus dibelah dan dibilas dengan $\mathrm{NaCl}$ fisiologis serta kemudian diamati permukaan lambung secara makroskopik setelah itu dilakukan skor lambung.

Berdasarkan data-data yang telah diperoleh yang kemudian dilakukan uji statistik maka diketahui bahwa terdapat adanya efek gastroprotektif dari ekstrak daun gedi hijau terhadap tikus yang diinduksi dengan aspirin. Adapun data penelitian tersebut akan dibahas di bawah ini.

Hasil uji statistik Mann Whitney untuk analisis skor lambung, diketahui terdapat perbedaan yang signifikan antara $\mathrm{K}(\mathrm{N})$ dan $\mathrm{K}(-) ; \mathrm{K}(\mathrm{N})$ dan $\mathrm{D} 1 ; \mathrm{K}(\mathrm{N})$ dan $\mathrm{D} 2 ; \mathrm{K}(+)$ dan D1; $\mathrm{K}(+)$ dan D2; K(-) dan $\mathrm{K}(+)$; $\mathrm{K}(-)$ dan D3; D2 dan D3; D1 dan D3. Serta juga terdapat perbedaan yang 
tidak signifikan antara $\mathrm{K}(\mathrm{N})$ dan $\mathrm{K}(+)$; $\mathrm{K}(\mathrm{N})$ dan D3; $\mathrm{K}(+)$ dan D3; K(-) dan D2; $\mathrm{k}(-)$ dan D1; D1 dan D2.

Kelompok kontrol normal $(\mathrm{K}(\mathrm{N}))$ yang hanya diberi suspensi $\mathrm{Na} \mathrm{CMC} 0,5 \%$ dan kelompok kontrol negatif $(\mathrm{K}(-))$ yang diberi aspirin terdapat perbedaan yang signifikan. Hal ini dapat dijelaskan karena kelompok kontrol normal tidak mendapatkan fakftor agresif dan defensif lambung sehingga keadaan lambung secara fisik tidak mengalami ulkus (lambung normal).Sedangkan kelompok kontrol negatif mendapatkan faktor agresif lambung tanpa mendapatkan faktor defensif lambung sehingga lambung mengalami ulkus.

Perbandingan antara kelompok kontrol positif $(\mathrm{K}(+))$ dan kontrol negatif $(\mathrm{K}(-))$ juga terdapat perbedaan yang signifikan. Pada kelompok kontrol positif, hewan uji diberi aspirin namun sebelumnya mendapatkan perlakuan pemberian suspensi sukralfat.Adanya perbedaan yang signifikan dapat dijelaskan karena pemberian sukralfat dapat memberikan perlindungan pada lambung dengan membentuk suatu lapisan kompleks.

Kelompok perlakuan kontrol normal $(\mathrm{K}(\mathrm{N}))$ dan kelompok uji dosis 1 (D1), kontrol normal $(\mathrm{K}(\mathrm{N}))$ dan kelompok uji dosis 2 (D2), kontrol positif $(\mathrm{K}(+))$ dan kelompok uji dosis 1 (D1) serta kontrol positif $(\mathrm{K}(+))$ dan kelompok uji dosis 2 (D2) juga terdapat perbedaan yang signifikan. Hal ini dapat dijelaskan bahwa ekstrak daun gedi hijau $100 \mathrm{mg} / \mathrm{kg}$ BB dan $200 \mathrm{mg} / \mathrm{kg}$ BB belum cukup memberikan perlindungan terhadap lambung dari kerusakan yang ditimbulkan oleh aspirin dibandingkan dengan sukralfat yang merupakan obat kimia yang dapat menyeimbangkan kerusakan lambung yang ditimbulkan aspirin dengan baik.

Perbandingan antara kontrol negatif (K(-)) dan kelompok uji dosis 3 (D3) juga memiliki perbedaan yang signifikan. Hal ini dapat dijelaskan karena dosis yang lebih tinggi yaitu $300 \mathrm{mg} / \mathrm{kg}$ BB dapat memberikan perlindungan pada lambung sehingga secara statistik terdapat perbedaan yang signifikan. Selanjutnya untuk perbandingan lainnya yaitu antara kelompok uji dosis 1 (D1) dan kelompok uji dosis 3 (D3) serta antara kelompok uji dosis 2 (D2) dan kelompok uji dosis 3 (D3) juga memiliki perbedaan yang signifikan. Hal tersebut dikarenakan dosis $100 \mathrm{mg} / \mathrm{kg}$ BB dan $200 \mathrm{mg} / \mathrm{kg}$ BB tidak maksimal dalam memberikan perlindungan terhadap lambung seperti yang diberikan oleh dosis ekstrak 300 $\mathrm{mg} / \mathrm{kg}$ BB. Sehingga semakin besar dosis ekstrak daun gedi hijau maka aktivitas gastroprotektif semakin baik. 
Perbandingan antara kelompok kontrol normal $(\mathrm{K}(\mathrm{N}))$ dan kontrol positif $(\mathrm{K}(+))$ serta kelompok kontrol normal $(\mathrm{K}(\mathrm{N}))$ dan kelompok uji dosis 3 (D3) tidak terdapat perbedaan yang signifikan. Hal ini menunjukkan bahwa ekstrak daun gedi hijau pada dosis $300 \mathrm{mg} / \mathrm{kg}$ BB memiliki aktifitas gastroprotektif setara dengan sukralfat. Sedangkan perbandingan antara kelompok kontrol negatif $(\mathrm{K}(-))$ dan kelompok uji dosis 1 (D1), kelompok kontrol negatif $(\mathrm{K}(-))$ dan kelompok uji dosis 2 (D2), serta kelompok uji dosis 1 (D1) dan kelompok uji dosis 2 (D2) juga menunjukan tidak ada perbedaan yang signifikan. Hal ini menandakan bahwa ekstrak daun gedi hijau dosis $100 \mathrm{mg} / \mathrm{kg}$ BB dan $200 \mathrm{mg} / \mathrm{kg}$ BB tidak dapat memberikan perlindungan pada lambung seperti yang dihasilkan pada penggunaan dosis $300 \mathrm{mg} / \mathrm{kg} \mathrm{BB}$.

Pada penelitian ini dilakukan penentuan indeks ulser dan persen inhibisi.Tujuan ditentukannya indeks ulser ialah untuk melihat perbandingan jumlah skor ulser terhadap jumlah hewan yang mengalami ulserasi sedangkan penentuan persen inhibisi ialah untuk melihat seberapa besar hambatan pembentukan ulser yang dinyatakan dalam satuan persen.Berdasarkan hasil perhitungan diketahui bahwa indeks ulser kelompok kontrol normal adalah 0 . Indeks ulser setelah induksi dengan aspirin untuk kelompok kontrol negatif adalah 2,75. Berdasarkan nilai indeks ulser, kelompok yang memberikan tingkat penyembuhan terbesar adalah kelompok uji dosis 3 (300 $\mathrm{mg} / \mathrm{kg}$ BB) dengan nilai indeks ulser adalah 0 yang sama dengan kelompok normal dan kontrol positif Sedangkan untuk persen inhibisi diketahui kelompok uji dosis 3 (300 mg/kg BB) memiliki persen inhibisi $100 \%$ yang mana sama dengan nilai persen inhibisi dari kelompok kontrol positif yaitu $100 \%$.

Aktivitas gastroprotektif yang diberikan oleh ekstrak daun gedi hijau disebabkan adanya golongan senyawa metabolit sekunder yang terdapat pada ekstrak daun gedi hijau yang diduga mampu memberikan aktivitas gastroprotektif.Golongan senyawa metabolit sekunder tersebut yaitu flavonoid, tannin, alkaloid dan saponin. Jenis flavonoid yang terdapat pada gedi hijau ialah golongan quercetin dengan mekanisme kerja farmakologi sebagai antioksidan, Platelet Activating Factor (PAF), meningkatkan produksi mukus, dan sebagai agen antihistamin serta dapat menghambat pertumbuhan H.pylori (Mota et al., 2009). Tanin memiliki aktivitas sebagai anstringen dan dapat mengendapkan protein membran mukosa (Vasconcelos et al., 2008). Alkaloid 
bekerja dengan cara menghambat pompa proton $\mathrm{H}^{+}, \mathrm{K}^{+}$ATPase serta dapat meningkatkan sekresi mukus (Nascimento et al., 2015). Sedangkan saponin memberikan aktivitas gastroprotektif melalui peningkatan fibronektin, selanjutnya gumpalan fibrin yang terbentuk akan menjadi dasar dalam proses reepitelisasi pada jaringan. Oleh karena itu bila gumpalan fibrin cepat terbentuk, maka fibroblas akan segera berproliferasi ke area luka untuk segera mengadakan pemulihan jaringan (Indraswary R, 2011).

\section{DAFTAR PUSTAKA}

Gilman, G., 2012, Dasar Farmakologi Terapi Edisi 10, Volume 4, Penerbit Buku Kedokteran EGC, Jakarta.

Indraswary, R, 2011, Efek Konsentrasi Ekstrak Buah Adas (Foeniculum vulgare Mill) Topikal Pada Epitelisasi Penyembuhan Luka Gingiva Labial Tikus Sparague Dwaley in Vivo, Majalah Ilmiah Sultan Agung Vol.XLIX, Juli 2011, Unissula

Joshi, S. V., Kedar, K.A., Markana, U.V., Lodha, S.R., Shah, P.D., Vyas, H.G., Vyas, R.B., Vyas, V.A., and Kalyankar, G.G., 2011, Alteration of Gastric Mucus Secretion in Rats Treated with Abelmoschus esculentus Seed Mucilage, Der Pharmacia Lettre, 3(5): 183-188.

Kumar, SS., Marela, SS., Vipin S., and Sharmistha, M., 2013, Evaluation of Anti-Ulcerogenic Potential of Abutilon indicum, International Research Journal of Pharmacy, 4(3):233-236.
Mbagwu, H., Jackson, C., Ekpo, M., Okopedi, E., Anah, V., and Ugwu, C., 2011.Gastroprotective Effects of Ethanolic Leaf Extract of Musa paradisiaca L.(Musaceae) in Rats. Journal of Chemical and Pharmaceutical Research, 3(3):322327.

Mota, K., Dias, G., Pinto, M., Ferreira, A., Brito, A., Lima, C., Filho, J., and Batista, L., 2009, Flavonoids With Gastroprotective Activity, Molecules (20):979-1012.

Mycek, M. J., 2001, Farmakologi Ulasan Bergambar Edisi 2, Widya Medika, Jakarta.

Nascimento, R.F., Sales, I.R., Formiga R., Filho, J.M.B., Sobral, M.V., Tavares, J.F., Diniz, M.F.F.M., Batista, L.M., 2015, Activity of Alkaloids on Peptic Ulcer: What's New?, Molecules 20(1) : 929-950.

Oloyede, Hussein O.B., Adaja, Matthew C., Ajiboye, Taofeek O., Salawu, and Musa O., 2015, Anti-ulcerogenic Activity of Aqueous Extract of Carica papaya Seed on Indomethacin-Induced Peptic Ulcer in Male Albino Rats, Journal of Integrative Medicine, 13(2):105-114.

Rivera, JO., AM, Loya., and R, Ceballos., 2013, Use of Herbal Medicines and Implication for Conventional Drug Therapy Medicinal Sciences, Alternative and Integrative Medicine.

Sari, Mun'im dan Kusumaningtyas 2011, Aktivitas Gastroprotektif Kombinasi Ekstrak Kulit Batang Mimba(Azadirachta indica A. Juss) dan Rimpang Kunyit (Curcuma domestica Linn.) pada Tikus Putih yang Diinduksi Asetosal, Jurnal Ilmu Kefarmasian Indonesia 11(2): $97-$ 101.

Vasconcelos, P.C.P., Andreo, M.A., Vilegas, W., and Pellizzon, C,H., 2008, Effect 
Mouri Pusa Tannins and Flavonoids on Prevention and Treatment Against Experimental Gastric Ulcer, J.Etnopharmacol, 131(1), 146-153. 